Swarthmore College

Works

\title{
Lesson Plan For Teaching Four Stories From Sandra Cisneros' "Woman Hollering Creek And Other Stories"
}

Peter Schmidt

Swarthmore College, pschmid1@swarthmore.edu

Follow this and additional works at: https://works.swarthmore.edu/fac-english-lit

Part of the English Language and Literature Commons

Let us know how access to these works benefits you

\section{Recommended Citation}

Peter Schmidt. (2017). "Lesson Plan For Teaching Four Stories From Sandra Cisneros' "Woman Hollering Creek And Other Stories'"'. English Literature Faculty Works. DOI: 10.24968/2476-2458.engl.360

https://works.swarthmore.edu/fac-english-lit/360

\section{(c) (1) (8)}

This work is licensed under a Creative Commons Attribution-Noncommercial 4.0 License

This work is brought to you for free by Swarthmore College Libraries' Works. It has been accepted for inclusion in English Literature Faculty Works by an authorized administrator of Works. For more information, please contact myworks@swarthmore.edu. 


\title{
Lesson Plans for Teaching Four Stories from Sandra Cisneros' Woman Hollering Creek and Other Stories (1991): "Eleven," "Barbie-Q," "Little Miracles, Kept Promises," and "Woman Hollering Creek"
}

\author{
Peter Schmidt \\ Swarthmore College
}

Sandra Cisneros' Woman Hollering Creek and Other Stories (1991) is assigned frequently in high school and undergraduate courses in English and American literature, Latinx literature, and other classes. This essay presents teaching strategies for Cisneros' short fiction by focusing on two stories that explore childhood-"Eleven" and "BarbieQ"- and two that treat difficult passages into adulthood, "Woman Hollering Creek" and "Little Miracles, Kept Promises."

\section{Learning Outcomes}

These lesson plans will provide teachers with resources to help high school or college/university students of all ethnicities appreciate these stories' richness and wisdom regarding coming-of-age experiences and the cultural history of both the U.S. and Mexico.

Students will be taught to appreciate and evaluate the stories as literature, including Cisneros' varied vocabulary, powerful sentences, daring metaphors, allusions, and story structure. All four stories also have rich and ambiguous endings that inspire students to debate how best to interpret them; the stories don't provide simplistic or feelgood resolutions.

Students will learn how to identify and research key references, such as to La Llorona, La Malinche, Virgen de Guadalupe, or Tonantzín; they will then learn how to apply that information back to the story itself, creating a deeper reading of its drama.

Students will explore how commodities (like Barbie dolls) and religious icons affect girls' and women's identities. "Barbie-Q," for instance, traces two protagonists influenced by stereotypical, commercialized ideals of femininity and whiteness. But is that story really just about brainwashing?

Students will be taught to use these tales to reflect on how popular commercial and religious cultures enforce negative stereotypes (especially regarding race, class, and Mexicana/Chicana identity), yet may also be used to question and undo those very same cultural scripts.

Cisneros' tales highlight experiencing trauma and then narrate how such pain may be at least partially healed within a community of others. Discussing these stories guided by these lesson plans should help students not only appreciate Cisneros' story-telling prowess, but also reflect on their own difficulties and gain strength. Así, estos cuentos son milagritos. 


\section{(Optional) Introductory Discussion Points}

The following two observations, the first by Cisneros herself, can help open consideration of Cisneros creative goals. In A House of My Own: Stories from My Life, Cisneros expresses her admiration for the Catalán writer Marcè Rodoreda:

"It is this precision at naming the unnameable that attracts me to Rodoreda, this woman, this writer, hardly little, adept at listening to those who do not speak, who are filled with great emotions, albeit mute to name them." (123)

Consider also sharing this point by the poet and critic Harryette Mullen:

Woman Hollering Creek contains "stories of a variety of women trying various means of escape, through resistance to traditional female socialization, through sexual and economic independence, self-fashioning, and feminist activism, as well as through fantasy, prayer, magic, and art." (8)

Discuss with students how they interpret either or both of these quotations. Why does Cisneros so value the "unnameable" or what's been made "mute"? How would they put Mullen's praise in their own words? In what ways do these quotations connect with your students' own thoughts and emotions when reading Cisneros?

\section{Lesson Plan for Teaching "Eleven” (Woman Hollering Creek, pp. 6-9)}

Since the story's short and dramatic, have 2-3 students read aloud portions of the story.

\section{Discussion questions}

Each will open up discussion in different ways:

The 11-year-old girl never names herself, though some of her classmates are named. Give reasons for and against why an author would not name her main character. Also, notice that the girl speaks her thoughts to "you"-which means like we feel (or should feel) as if she's speaking directly to $u s$. How is this fact important for interpreting the story?

Why is the girl so upset about a sweater? Look at how Cisneros' writing vividly uses the present tense to place us in the girl's imagination. One example: discuss the paragraph in the middle of p. 8 beginning with the sentence "But when the sick feeling goes away and I open my eyes" and ending "Not mine, not mine, not mine."

What else occurs in the classroom - between the teacher and the girl, and the girl vs. her classmates - that upset her? What does Mrs. Price say to the girl, and why do you think the teacher behaves as she does? (Is the teacher certain that the red sweater is the girl's?) How do you feel about how the teacher treats the girl?

Why does it help or hurt the girl to imagine that she's not only 11 , she's also 10 , 9 , 8, etc.? Look in particular at the opening statement the girl makes about the paradox of age (pp. 6-7). 
Although Mrs. Price's (the teacher's) humiliation of the girl is unforgettable, this story is arguably not just a story about victimization. Do you agree or disagree? Point to evidence in the story to support your interpretation.

The last two pages of the story contain references to the family's upcoming birthday celebration for the heroine, particularly the cake her mother will bake for her. Why in the final sentence does the girl imagine the events of her day as a tiny "runaway" balloon" floating away from her?

Nearly the entire story is composed of words that the girl does NOT say to the teacher or her classmates, only to herself. Why is that important? Consider the possible relevance of Cisneros' comment on the author Marcè Rodoreda, quoted above.

What unanswered questions does "Eleven" leave you with?

Teachers may use some of the above topics to focus discussion, and others as topics for assigning reflection papers.

\section{Lesson Plan for Teaching “Barbie-Q” (Woman Hollering Creek, pp. 14-16)}

How should we respond to the voice of the narrator, as she speaks both to a friend ("you") and to us, the reader? Consider these details: The story opens with the narrator addressing a friend and listing what's "yours" vs. what's "mine." Is this story really just about possessive individualism?

What is the role of directly addressing the reader? Examples: "Only Ken's invisible, right?" (p. 14); "see there?" (bottom of p. 15); the "so what" and "who's to know" questions in the story's last paragraph (p. 16). Why is this important? How does it help us enter into the larger questions the story is asking regarding how consumers create virtual worlds using the popular cultural commodities that capture their imagination?

No quotation marks are used by the narrator, except to refer to Barbie Doll costume sets that have been copyrighted by Barbie's corporate owner and creator, Mattel. ("Solo in the Spotlight" etc.) The narrator's voice often sounds very much as if the language of Mattel advertising has become part of her "inner" voice. One of many examples: "the 'Career Gal' ensemble, snappy black-and-white business suit, threequarter-length sleeve jacket with kick-pleat skirt, red sleeveless shell, gloves, pumps, and matching hat included" (15).

- Have the students debate how we should interpret the above example. Is this an instance of what cultural critic Theodor Adorno would call "pseudoindividuality" - that is, instances of how our very individualism has been completely defined by commodities, and we define our individualism by the things we possess? (For brief summaries of Adorno, see Ross and Parker.)

Look at the girls' descriptions of the various Barbies. What markers, if any, of race or ethnicity do they have?

"Every time the same story": but what is that story? Does Cisneros' story have a feminist component? That is, are the girls learning via their Barbie dolls to see 
themselves as sex objects for an absent male gaze, or as "white"? Or are they via their play creating a female-centered and Chicana sense of community and validation, a "we"? ("we have to make do": p. 15). Three key quotations to consider:

- "Every time the same story. Your Barbie is roommates with my Barbie, and my Barbie's boyfriend comes over and your Barbie seals him, okay? Kiss kiss kiss. Then the two Barbies fight. You dumbbell! He's mine. Oh no he's not, you stinky!" (p. 14)

- Yet: "Only Ken's invisible, right? Because we don't have money for a stupidlooking boy doll..."

- In the final paragraph, what's really being asserted in the "so what?" and "who's to know" questions?

Does the girls' play reinforce the idea that a women's worth is defined by who gets the man, whose gaze and power can be present even when he is absent? Or would students interpret the girls' play differently, as activity where the girls can mock fighting each other for the guy rather than merely imitating that behavior? Does this mean they are beginning to be conscious of the dangers of understanding a woman's value solely through possession (or being a possession) of a man?

Race and class intersect with gender in this story. The Barbie dolls-except for their burnt feet, which the girls joke about, thus giving the story its title-represent an ideal of white female beauty and wealth. In coveting these dolls, are the girls being taught to devalue their identity as working-class Chicanas? By playing with these dolls, are the girls learning to devalue their identity as working-class Chicanas? Or is the community the girls create by playing together and saying "so what?" (16) superseding a desire to be exactly like the Barbies?

Students should debate the merits of the above considerations and interpretations, which might be called the "brainwashed consumer" vs. the "community and womanhood" interpretations, or "shame" vs. "pride" readings.

That is, one possible summary of the story suggests it is about the successful brainwashing of the girls, and that their enthusiasm for the dolls covers up their shame. Rivera: Cisnero's story "confronts notions of poverty and female beauty through the acquisition of damaged Barbie dolls and the covering up of physical imperfections that do not meet the standards of traditional concepts of beauty" (43).

A different reading could be that the girls' enthusiasm and their concluding questions aggressively push back against those who would mock them, asserting the girls' own right to pride and a community, a Chicana "we" that they themselves have successfully made. "[W]ho's to know?" (p. 16) — could this be a boast, rather than admission of shame? Doesn't it imply that the friendship circle is secret, unknown to most, and therefore of great value to them?

Which of these two readings do students find more persuasive, and why? Debating these viewpoints will generate good discussion, and focused reflection papers.

A concluding note. With all of the above topics - gender roles, "white" stereotypes of beauty, commodity consumption, and class status-Cisneros' story 
arguably doesn't offer us a definitive conclusion about whether the girls' behavior is good or bad, delusional or praiseworthy. It just presents it in their voice, brimming with excitement and ecstatic present action ("there! And there! and there!").

- Is the story's refusal to judge the girls' interaction with a product of the Mattel Corporation a strength or weakness?

Optional Online Resources and Student Research Projects for "Barbie-Q," including background on the Maxwell Street market in Chicago and debates about mass market popular culture and how consumers interact with it:

See Peter Schmidt's academia.edu website and check for the Cisneros Research Projects document in the Teaching Documents section: https://swarthmore.academia.edu/PeterSchmidt

\section{Lesson Plan for Teaching "Little Miracles, Kept Promises" (Woman Hollering Creek, pp. 116-24)}

Cisneros' story is composed of many writings by others that accompanied small charms left to honor the Virgin Mary (or other saints or sacred beings) for healing miracles, in the manner of ex-votos. Milagritos, or little miracles, often have the form of the organ or body part healed; they are "miniature charms depicting parts of the body such as the heart, hands, and legs. Placed at a shrine that is considered to have miraculous power, they are attached to the clothing of the saint's statue responsible for the miracle" (Pineda 368). An accompanying note, if one is left, is a prayer for help, or honors the ways in which the Virgin miraculously interceded in someone's life to make it better. Collectively, these accounts tell the story of a community.

\section{DISCUSSION TOPICS}

\section{Topic One: On Milagritos}

Since the story begins the way it does, consider the ways in which Cisneros' story is a portrait not just of individual people and their notes, but also of a community under stress. Look at the following particular milagrito notes (and you may nominate a few others to discuss too): Adelfia's (117), Barbara's (117-18), Arnulfo's (120), and Teresa's (121-22).

- What personalities do these figures display, as shown by their writing voice, including both how they describe their crisis and how they give thanks?

- What is the importance of the story's double title, "Little Miracles, Kept Promises"?

- In acknowledging the Virgin, are the characters are placing all agency and power outside of themselves, in Her? Or do you think Her succor also ignites a kind of power in the people themselves? Point to the wording in the stories to give evidence in support of your view. What does posing this question tell us about the power and mystery of religious belief, in your opinion? Encourage students 
either in small groups or in reflection papers to indicate passages to support their answers to these questions, and to discuss the power and mystery of religious and cultural beliefs in contemporary society.

- Some of the milagrito stories reveal relatively happy resolutions. Other endings are left ambiguous; the reader doesn't know if the prayer was answered. Why do you think Cisneros included such a mix?

Collectively, these stories also tell us the story of a community, la gente or mi pueblo in Spanish. What general themes emerge about the challenges this community confronts and how they are met?

\section{Topic Two: Portrait of the Artist as a Chicana Feminist: The Emergence of Chayo} At the conclusion to "Little Miracles," the story's format changes. Instead of just a brief note from her (given at the story's conclusion), we get an extended transcription of the thoughts and experiences of a particular person, Rosario "Chayo" De Leon of Austin, Texas.

The concluding sequence (pp. 124-29) acts as a portrait of the artist as a young woman experiencing a transformation in how she thinks about herself and her destiny. She bears bears some resemblances to both the painter Frida Kahlo and Sandra Cisneros.

This final section of the story (pp. 124-29) is presented as a long "note" or prayer to La Virgen de Guadalupe, accompanied by a long "braid" of Chayo's hair that she has cut off and pinned to La Virgen's statue, giving thanks for receiving the strength to begin a new life as an artist (124). Rivera interprets the gift of her cut braid to La Virgen as signifying "rebirth" (48), stressing this quotation from Chayo: "my head as light as if I'd raised it from water" (Woman Hollering Creek 125).

Key to Chayo's emergence as an artist is her discovery of a connection between La Virgen de Guadalupe, the patron saint of Mexico, and the Aztec or Nahua earth goddess Tonantzín, whom Chayo comes to realize is La Virgen's antecedent. Tonantzín's temple was built on Tepeyac hill in Tenochtitlán but was razed by the Spanish soon after the conquest of the city (1519-21). After the peasant Juan Diego had repeated visions of the Virgin Mary on or near the same site in December 1531, the first of several basilicas honoring Our Lady of Guadalupe was constructed. The current basilica on Tepeyac hill in Mexico City is one of the most visited Catholic shrines in the world. La Virgen de Guadalupe is associated with the Virgin Mary, but she also became a saint in her own right—in fact, she was the first dark-skinned Mexican saint recognized by the Catholic church. She is honored throughout Latin America, particularly in Mexico, and by Latinos in the U.S. Depictions of her normally emphasize her dark brown skin (Gonzáles-Berry).

Chayo explores the inspiration given to her by three powerful women: the Virgin Mary, La Virgen de Guadalupe, and Tonantzín. For Chayo they become a kind of womencentric Trinity: three separate but united forces for spiritual healing. Chayo's synthesis linking these three powerful women changes her mind about the meaning of La Virgin de 
Guadalupe story. Chayo's new perspective towards these miraculous women gives her confidence in her own destiny to be an independent artist.

To explore these themes, have students seek to answer the following questions:

- At first Chayo associates La Virgen with subservience and suffering, refusing to allow images of her where she lives. ("For a long time I wouldn't let you in my house" [127]). Since La Virgen de Guadalupe is the patron saint of Mexico and of Chicanos as well, with images of her everywhere, including in homes, Chayo's initial refusal to honor her is not a trivial or minor act on Chayo's part. How should we understand Chayo's act?

- How is Chayo affected by the constant comments she hears from family and friends urging her to abandon her dreams to be a painter and to be a more conventional, less "selfish" woman? See especially pp. 125-26. Note that Chayo "hears" these voices criticizing her even when she's alone.

- What qualities does Chayo admire in Tonantzín? How does discovering a possible link between Tonantzín and La Virgen change Chayo's understanding of the meaning of La Virgen for her? See in particular pp. 127-28.

\section{Optional Online Resources and Research Projects on "Little Miracles, Kept} Promises," covering milagritos, Tonantzín, the story’s Frida Kahlo allusion, and other topics:

See Peter Schmidt's Academia.edu webpage and check for the Cisneros Research Projects document in the Teaching Documents section: https://swarthmore.academia.edu/PeterSchmidt

\section{Lesson Plan for Teaching "Woman Hollering Creek" (Woman Hollering Creek, pp.} 43-56).

This is a story where social and geographical spaces are marked by thresholds or border crossings where expectations are dashed. Yet out of those same spaces may emerge new possibilities. Cisneros' story explores both outcomes.

\section{DISCUSSION TOPICS}

Spaces in the story marked by thresholds or border crossings

Find some references to thresholds, borders, arroyos, even edges. Who are the dominant figures in these spaces and boundaries, and how does Cleófilas relate to them? Have students make some lists and discuss them. Are all the "gods" of these spaces or borderlines all male?

Great expectations become dashed

What are some examples of disillusionment in the story? What causes the changes that Cleófilas experiences? 
Entrapped in repetition (not a change but an entrapment)

List a few examples of repetition in the story, both at the level of individual sentence, paragraphs, or larger structures within the story (the individual sections).

- Here is one passage that would be a good candidate for having the class read closely; it occurs when Cleófilas is beaten by Juan Pedro for the first time:

Instead, when it happened the first time, when they were barely man and wife, she had been so stunned, it left her speechless, motionless, numb. She had done nothing but reach up to the heat on her mouth and stare at the blood on her hand as if even then she didn't understand.

She could think of nothing to say, said nothing. Just stroked the dark curls of the man who wept and would weep like a child, his tears of repentance and shame, this time and each." (48)

Why does this passage use "it" in the first sentence, with the pronoun's referent so unclear? Although the passage opens with the phrase "the first time," it ends with the phrase "this time and each": what does this shift suggest? Although the quotation stresses Cleófilas as "speechless, motionless, and numb," does it also give her a voice and agency, even at this low point in her life?

Commercial popular culture (including telenovelas) and the shaping of gender roles What Cleófilas had been waiting for in her life was "passion" (44). She learns what passion is from the telenovelas that everyone watches. Have students read carefully the narrator's description of what she calls the most popular telenovela, Tú o Nadie," ["You or No One"], pp. 44-45:

- Who is speaking in this passage and who is being addressed? What affect does it have when the story directly addresses us, the readers, in a passage like this one?

$\circ$ Note the powerful authority the passage claims when describing what real passion is: "Somehow one ought to live one's life like that, don't you think?" (45). How should a woman live her life, according to the narrator in this passage?

- For advanced students, have them do brief research on the story-telling concept of "free indirect narration"-what is free indirect narration and why do they think Cisneros employs this narrative technique on pp. 44-45 for the telenovela passage? In writing such passages, does that mean the author endorses its view of the world, what women should feel and believe?

○ Are there other moments in "Woman Hollering Creek" when the "free indirect" technique is used?

Cisneros' story also suggests that workplaces and other locations, including bars, shape how men understand themselves as strongly as telenovelas shape women. Have students study the "ice house" section of the story (p. 48).

- What is "the truth" that the men want to tell each other?

- What references in this passage suggest the men are not successful in defining their masculinity through their "fists"?

- What is the function of this section within the story as a whole? 
Note: A goal for this part of the discussion would be for students to realize how Cisneros' story deftly uses dramatic irony to critique how telenovelas teach their viewers how to internalize the view that love = suffering and that women just have to accept and endure this, even when they are beaten: "the pain all sweet somehow. In the end." (45).

Here are questions for students to explore all these topics further:

- If both men and women internalize scripts about proper gender roles from commercial culture as well as from religious teachings, does Cisneros' story suggest that a protagonist like Cleófilas is doomed to do this forever?

- Or is there any hope for her to cross the threshold from that way of being to a new way?

- What parallels and differences do students see in this story's treatment of telenovelas and "Barbie-Q"'s treatment of popular culture?

Discuss the portraits of Graciela and Felice in "Woman Hollering Creek":

- What does Cleófilas notice about these two women?

- In what different ways do these women challenge traditional definitions of "proper womanhood"? They are very "modern," yet they seem less influenced than many women are by pop culture stereotypes drawn from telenovelas - why not?

- Why does Cisneros narrate their scenes primarily using dialogue?

What different meanings do "crying" or "hollering" gain over the course of the story?

- "No one could tell if the woman had hollered from anger or pain" (46).

- How would students describe Felice's scream at the end of the story and its effect on Cleófilas, where Felice's shout is described as a kind of laughter "gurgling out of her own [Cleófilas'] throat, a long ribbon of laughter, like water" (56)?

- An interesting advanced topic: what role do other sounds play in the story? Many are not just referenced but enacted. Here are just examples from just two pages: the melancholy sound of the pecan tree leaves (44) and the "rrrr" of sewing machines and the narrator exclaiming "izas!" (45).

- The importance of all of these sounds arguably culminates with the story's final sentence (56). Why does this sentence make for a powerful ending to the tale?

As in the previous lesson plans above, these topics and questions on "Woman Hollering Creek" may make for good paper topics for students, as well as guides for class discussion.

Further Discussion Questions and Optional Online and Print Research Projects for High School and College/University Students on La Llorona, La Malinche, and Tonantzín:

See Peter Schmidt's Academia.edu webpage and check for the Cisneros Research Projects document in the Teaching Documents section: https://swarthmore.academia.edu/PeterSchmidt 
Thanks to Elizabeth Martínez of DePaul University in Chicago for some helpful suggestions.

\section{WORKS CITED}

Theodor W. Adorno, and Max Horkheimer. "The Culture Industry: Enlightenment as Mass Deception." Dialectic of Enlightenment. Transl. John Cumming [1944]. New York: Herder and Herder Press, 1972. 120-167. Rpt. with a new translation in Dialectic of Enlightenment: Philosophical Fragments. Transl. Edmund Jephcott. Stanford: Stanford University Press, 2002. 94-136.

Cisneros, Sandra. Woman Hollering Creek and Other Stories. New York: Random House, 1991.

Cisneros, Sandra. A House of My Own: Stories From My Life. New York: Knopf, 2015.

Gonzáles-Berry, Erlinda. "Review of Woman Hollering Creek and Other Stories, by Sandra Cisneros." The Americas Review 20.1 (Spring 1991): 84-85.

Mullen, Harryette. "A Silence Between Us Like a Language: The Untranslatability of Experience in Woman Hollering Creek.” MELUS 21.2 (Summer 1996): 8.

Parker, Holt M. "Toward a Definition of Popular Culture." History and Theory 50 (May, 2011): 147-70.

Pineda, Ana María, R.S.M. "Imagenes de Dios en el Camino: Retablos, Ex-Votos, Milagritos, and Murals." Theological Studies 55 (2004): 364-79.

Rivera, Carmen Haydée. Border Crossings and Beyond: The Life and Works of Sandra Ciseros. Greenwood Publishing Group/Santa Barbara: ABC-CLIO, 2009. [See pp. 42-51 for Rivera's main discussion of Woman Hollering Creek.]

Ross, Alex. "The Naysayers: Walter Benjamin, Theodor Adorno, and the Critique of Pop Culture." The New Yorker. September 15, 2014. Web: http://www.newyorker.com/magazine/2014/09/15/naysayers. 